\title{
Learning History through Historical Movies: Bringing Living History into Classroom
}

\author{
Muhammad Azmi ${ }^{1}$ \\ ${ }^{1}$ Mulawarman University, Banggeris Street Number 89, Samarinda, Indonesia
}

\begin{abstract}
Learning history would be done in various ways. In traditional learning, history learned by reading a book or hearing a story about the past or simulates the past with role-playing. In the digital era, history learned by the student with digital forms, such as multimedia learning, mobile learning and historical movies. At this time, there is a trend to revive the feeling of the past in the present day known as living history. Implementing living history is really difficult in terms of cost and time to get it into the classroom. Thus, historical movies are alternative ways of conveying the historical atmosphere in the classroom. This paper will distinguish a learning model design that uses historical movies as an instructional medium to bringing living history into the classroom. The literature referenced in this paper used to analyze implementing living history through historical movies to bring it into the classroom. The conclusion in this paper is the living history would be to learn through historical movies.
\end{abstract}

\section{Keywords: learning history; historical movies; living history}

\section{INTRODUCTION}

We are familiar with a statement about long life learning. Coles and Armstrong [1] states the learning history as a time of leisure. Besides, Hunt [2] prefers to use phrase 'serious leisure pursuit'. In the United Kingdom, Living History Society involved in film and television work. The members of society appeared in films such as The Lord of the Rings, Gladiator and television programs, such as Simon Schama's History of Britain and archaeological series, Time Team. Even, members also visit schools and demonstrates historical event that relevant with topics according to UK's National Curriculum (Coles \& Armstrong [1])

There are various ways for learning history. Learning history usually through reading a book and listening to a story as the conventional way. In the other way, learning history also through modern ways, such as multimedia and other digital forms. Azmi \& Jamil [3], Umbara \& Hermawan [4] and Wahyudhi [5] found that learning history also could be through games. As an education material, Nastiti, Isnanto, \& Martono [6] found that history would be transformed to digital form through multimedia. Besides, Azmi, Joebagio, \& Suryani [7] found that history also learned with mobile learning as instructional media. 
Technological advances and technological sophistication in film making, such as green screen and computer generated image make historical movies capable of bringing the atmosphere of the past into a film as real as possible. Movies as instructional media for history can allow the audience to experience the atmosphere of the events in the past through audio-visual presented. This paper will discuss how to learn living history through the movies to feel and see the past lives in audio-visual. The discussion in this paper divided into three parts; the challenge of living history implementation, movies as instructional media for history, and design model of living history in the classroom.

\section{METHOD}

The method used in this paper is a literature study. The literature is journal paper, research paper, book and other references which are relevant to the topic. The synopsis of movies is also referenced in this paper as discussion material.

\section{LIVING HISTORY: CHALLENGE FOR IMPLEMENTATION}

Anderson [8] defines living history as 'the simulation of life in another time'. He believed the simulation could be divided into three areas; that is, connected with museums, archaeology, and reenactment. Every area has the challenge to carry out it in the real world. Besides, Gordon [9] offers the way of learning history with term "Tourism History".

Museums have been found in almost every regions of the world, not least in Indonesia. The simulation connected with the museum is basically showing off various relics of the past, so it shows people's lives description during that period. Terry [10] do research on three existing living history museum in Canada; Dundurn Castle in Hamilton, William Lyon Mackenzie House in Toronto, Ontario and the Sir GeorgeEtienne Cartier National Historic Site in Montréal, Quebec. He did research with corporate traditions and activities carried out at the time of the Victorian Christmas each year. It aims to see living history in action carried out by the local community. Archaeological sites closely related to the relics of the past place. This site usually has rules to avoid the relic from destruction. Living history with archaeological site done by visiting that site to get a description of the relics of the past. Reenactment usually connected with role playing. The term "historical re-enactment" defined with the staging of an event or activity from the past. This term usually used for event or habit in the past in a theatrical collision between performer and audience. Giles explains reenactment as the past recreation. And usually displayed as a leisure activity by enthusiast to attract visitors (Hamid, 2015).

In the educational world, teachers try to make the learning fun. In Indonesia, the three areas for living history cannot implement in the classroom. Firstly, living history connected with the museum, for example, requires time and funds to visit the museum. This is certainly going a burden for teachers and students in arranging visits to museum activities. Secondly, the living history connected with archaeology site also meet constraints in implementing it. In Indonesia, the most archaeology site scattered in various areas. Therefore, living history implementation connected with archaeology site 
will have a burden in terms of time and funding as it's connected with the museums. Thirdly, the living history implementation with re-enactment also meets the burden. The activity takes a lot of time in preparation. This will keep the class busy for the preparation. In addition, venues availability to show living history will also make it difficult for teachers and students. Re-enactment takes time, place and funds, such as preparation of venue, time preparation for the event, and fund preparation for costumes.

\section{MOVIES AS INSTRUCTIONAL MEDIA FOR HISTORY}

The ideal instructional media for history at least have the basic criteria of an instructional media as described by Sudjana \& Rivai [11] in terms of economically, practicality, ease retrieved, flexibility and conformity with the purpose of learning. Historical movies as an instructional media for history meets the five criteria above. Historical movies usually obtained from various video sharing sites on the internet, particularly on YouTube. Documentary films and short films multitudinous usually found on the first video sharing site in the world. In addition, teachers also find plenty of historical movies that fit the learning objectives. The advantages of using historical movies are flexible because it played on any devices and software, thus making the movies became very practical and simple in implementing it.

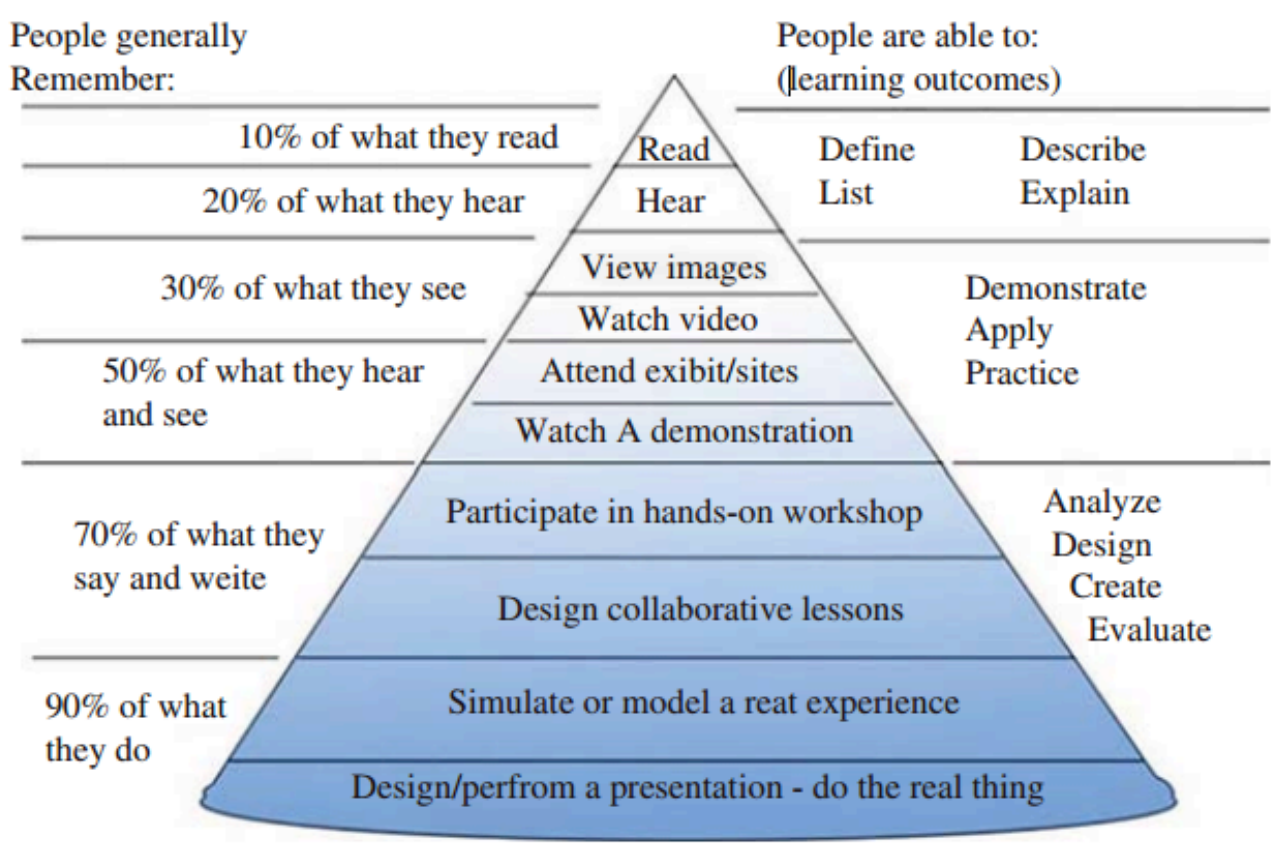

Figure 1 Edger Dale's Cone Experience

Edgar Dale's Cone of Experience has a positive impact on student learning (Davis \& Summers [12]). Movies as instructional media contain the audio and visual form. According to Cone experience above, learning with audio-visual remembered by the learner for $30 \%$ of what they see. Therefore, the necessary supporting instruments that 
can help learners to understand what they learn from the movie. The following table is a list of some movies that would be used in the study of living history. This table has information about the title of movies, region, and country of the background story of the movies.

TABLE I. THE LIST OF SOME MOVIES TO LEARNING LIVING HISTORY

\begin{tabular}{|ccc|}
\hline Title & Region & Country \\
\hline Agora & North Africa & Egypt \\
Gladiator & Rome & Italia \\
The Kingdom of Heaven & Europe & Jerusalem \\
The Duchess & Europe & England \\
Journey to Mecca & Middle East & Mecca \\
Ashoka The Great & South Asia & India \\
Dragon Blade & East Asia & China \\
The Last Samurai & East Asia & Japan \\
\hline
\end{tabular}

Agora is a historical drama set in Roman Egypt that tells about a slave who turns to the rising tide of Christianity hopes freedom and falls in love with his mistress, Hypatia of Alexandria. Besides, Gladiator has a background story of Roman that informs about the event in AD 180 that concern to General Maximus Decimus Meridius who leads the Roman Army against the Germanic tribes near Vindobona on the Limes Germanicus.

In addition, The Kingdom of Heaven tells the story of the Crusades in the 12th century. Besides, The Duchess also has information about the life of the Duchess in the late 18th century. Accordingly, Journey to Mecca tells the story about Ibn Battuta who travels around the world in the 14th century that has information about his journey from Morocco to Mecca for the Hajj in 1325.

Therewith, Ashoka The Great has information about the tale of the King Asoka's life in India as a king of Maurya dynasty at the ancient time of Indian subcontinent in 273 BC to 232 BC. Furthermore, Dragon Blade is a movie tells us about The Silk Road Protection Squad's life that set in 48 BC in northwest China. The information in this movie would learn is the connection between west and east in Silk Road. In the other, The Last Samurai set in 19th Century Japan inspired by 1877 Satsuma Rebellion led by Saigo Sakamoto. According to some movies above, the learner can get information about different time, place, period and event of history in every region.

\section{BRINGING LIVING HISTORY INTO CLASSROOM}

Collingwood [13] suggests six aspects to consider in implementing living history; the body of knowledge, chronological and causality of the event, improvisation, class management, a brief response that attracts attention, and an interesting storyline that associated with the daily experience. Bringing living history into the classroom is not easy. However, with the development of digital technology, living history can study through various ways, including through the movie. Figure 2 below will explain steps of learning about living history through movies. 
Specify Learning Objectives
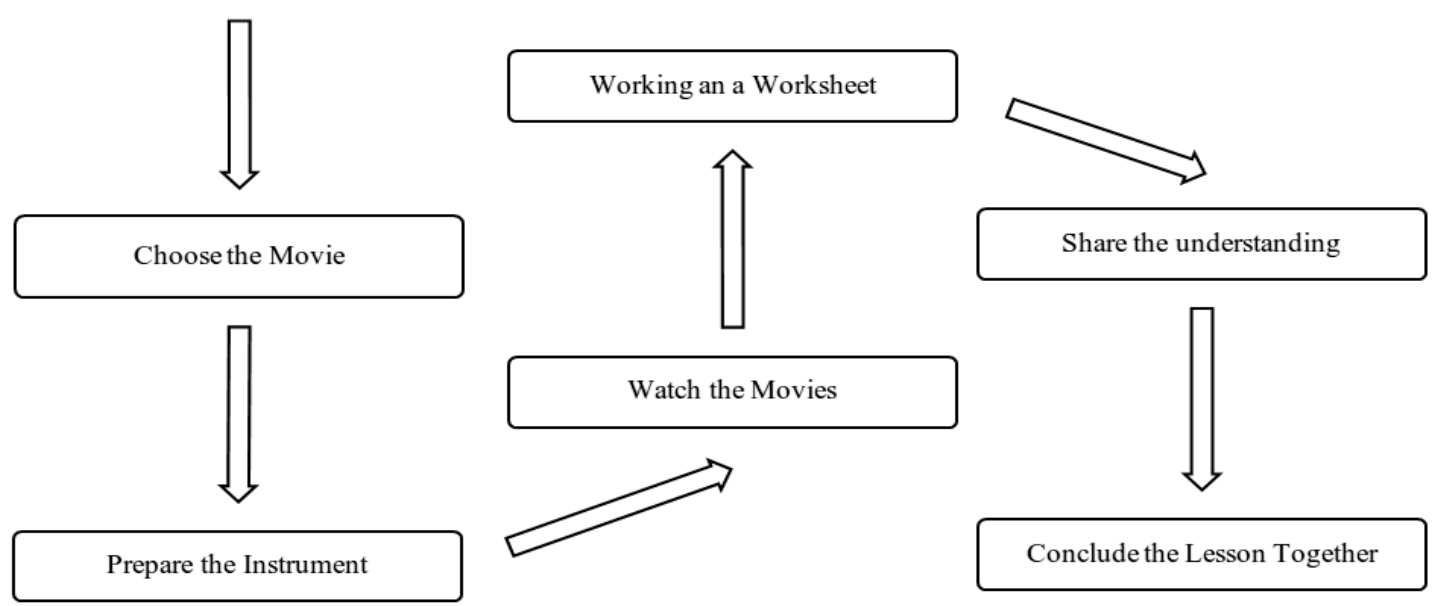

Figure 2. Seven Steps of Leaning Living History through Movies

Based on figure 2 above, there are seven steps in the learning of living history through movies with the following explanation.

\section{Specify Learning Objectives}

The first stage, educators are welcome to decide in advance the learning objectives based on the curriculum. The purpose of this study will be the basis for determining the movie that used to prepare the instruments.

\section{Choose the Movie}

The second stage is selecting the movie based on the learning objectives that determined at earlier stages. This determines considering the matter, the period and areas that serve as the subject.

\section{Prepare the Instrument}

The third stage is instrument preparation. This step is done by preparing the instrument according to the purposes of learning based on learning objectives. The instrument will have a list of questions, checklist, worksheets, or task list. The list should contain questions about space and time in the historical movie, the condition of the environment and the community. In addition, it is necessary also the question about the main character who becomes the perpetrator of history and the important events that happen in the movie. 


\section{Watch the Movie}

On the fourth stage, students are welcome to watch a movie that determined and guided by the teacher in the classroom. Before the movie begins, each student is given a worksheet as a guide to the task that done when watching the movie is finished

\section{Working a Worksheet}

On the fifth stage, students are welcome to work on the worksheet that distributed before. The purpose of this activity is to know the level of understanding and perception of students toward historical events presented in the movie.

\section{Share the Understanding}

On this sixth stage, teachers invite students to share their perceptions and understanding in the form of discussion. In this activity, each student has the opportunity to share opinion against the events presented in the movie.

\section{Conclude the Lesson Together}

The last stage, teachers and students create a shared conclusion. At this stage, the teacher gives the opportunity to the students to make conclusions about the lesson. Teachers hold all the conclusions that articulated by students and then together make final conclusions.

\section{CONCLUSION}

As conventional ways, there are three areas for learning of living history; museum, archaeological site and reenactment. Besides, living history implementation in classroom meets the burden in time, place and fund. But, technological developments offer ease for learning of living history through historical movies. It makes learning more flexible, because it played on any devices and software, thus making the movies became very practical and simple in implementing it. Learning of Living history through movies according to seven steps: specifying of object learning, choosing the movie, instrument preparation, watching a movie, working on a worksheet, understanding sharing, and making conclusion together.

\section{REFERENCES}

[1] Coles, J., \& Armstrong, P. (2008). Living history: learning through re-enactment. Retrieved from http://www.leeds.ac.uk/educol/documents/172304.pdf

[2] Hunt, S. J. (2004). Acting the part: "living history" as a serious leisure pursuit. Leisure Studies, 23(4), 387-403. https://doi.org/10.1080/0261436042000231664

[3] Azmi, M., \& Jamil. (2016). Developing Game Based on Historical Event with RPG Maker MV. In International Conference on Learning Innovation and Quality Education (pp. 1-9). Surakarta: UNS Press. 
[4] Umbara, D. J., \& Hermawan, G. (2013). Game Edukasi untuk Pembelajaran Sejarah Kemerdekaan Indonesia 1) 2). The 14th Seminar on Intelligent Technology And Its Applications, 321-325.

[5] Wahyudhi, J. (2014). Video Game Sebagai Media Pembelajaran Sejarah ( Suatu Alternatif dalam Menyelenggarakan Pembelajaran Sejarah ). Sosio Didaktika, 1(2). Retrieved from http://journal.uinjkt.ac.id/index.php/SOSIO-FITK/article/viewFile/1262/1128

[6] Nastiti, A., Isnanto, R. R., \& Martono, K. T. (2015). Aplikasi Multimedia sebagai Media Pembelajaran Sejarah Indonesia Masa Perjuangan Kemerdekaan Untuk Sekolah Dasar Berbasis Android. Jurnal Teknologi Dan Sistem Komputer, 3(4), 512. https://doi.org/10.14710/jtsiskom.3.4.2015.512-522

[7] Azmi, M., Joebagio, H., \& Suryani, N. (2016). The Comprehension of Local History with the Use of Mobile Learning Electronic Devices: The Establishment of the Islamic Era and the Banjar Sultanate in South Kalimantan. In International Indonesia Forum for Asian Studies Conference (pp. 585-590). Surakarta: Pramudita Press.

[8] Anderson, J. (1982). Living History: Simulating Everyday Life in Living Museums. Source: American Quarterly, 34(3), 290-306. https://doi.org/10.2307/2712780

[9] Gordon, A. (2016). Time Travel: Tourism and the Rise of the Living History Museum in MidTwentieth-Century Canada. Toronto: UBCPress. Retrieved from http://www.ubcpress.ca/books/pdf/chapters/2016/TimeTravel.pdf

[10] Terry, A. (2010). "LIVING HISTORY" IN CANADA: Representing Victorian Culture In The Multicultural Present. Retrieved from http://qspace.library.queensu.ca/bitstream/handle/1974/13885/Terry_Andrea_201008_PhD.pdf?se quence $=1 \&$ is Allowed $=\mathrm{y}$

[11] Sudjana, N., \& Rivai, A. (2007). Teknologi Pengajaran. Bandung: Sinar Baru Algensindo.

[12] Davis, B., \& Summers, M. (2015). Applying Dale's Cone of Experience to increase learning and retention: A study of student learning in a foundational leadership course. Qscience Proceedings, 6.

[13] Collingwood, R. G. (2004). Filsafat Sejarah: Investigasi Historis dan Arkeologis. (M. Kepata, Ed.). Yogyakarta: Insight Reference. 